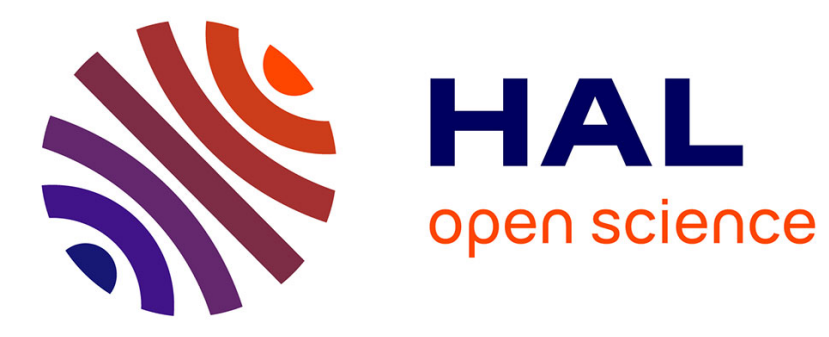

\title{
Recognition of the persistent organic pollutant chlordecone by a hemicryptophane cage
}

Augustin Long, Sara Lefevre, Laure Guy, Vincent Robert, Jean-Pierre

Dutasta, Marion Chevallier, Oriane Della-Negra, Pierre-Loïc Saaidi,

Alexandre Martinez

\section{To cite this version:}

Augustin Long, Sara Lefevre, Laure Guy, Vincent Robert, Jean-Pierre Dutasta, et al.. Recognition of the persistent organic pollutant chlordecone by a hemicryptophane cage. New Journal of Chemistry, 2019, 43 (26), pp.10222-10226. 10.1039/c9nj01674k . hal-02527910

\section{HAL Id: hal-02527910 \\ https://hal.science/hal-02527910}

Submitted on 1 Apr 2020

HAL is a multi-disciplinary open access archive for the deposit and dissemination of scientific research documents, whether they are published or not. The documents may come from teaching and research institutions in France or abroad, or from public or private research centers.
L'archive ouverte pluridisciplinaire HAL, est destinée au dépôt et à la diffusion de documents scientifiques de niveau recherche, publiés ou non, émanant des établissements d'enseignement et de recherche français ou étrangers, des laboratoires publics ou privés. 


\title{
Recognition of the persistent organic pollutant chlordecone by a hemicryptophane cage
}

\author{
Augustin Long, ${ }^{a}$ Sara Lefevre, ${ }^{b}$ Laure Guy, ${ }^{b}$ Vincent Robert, (D) c \\ Jean-Pierre Dutasta, (D) ${ }^{b}$ Marion L. Chevallier, ${ }^{d}$ Oriane Della-Negra, (D) ${ }^{d}$ \\ Pierre-Loïc Saaidi (i) *d and Alexandre Martinez (iD *a
}

\begin{abstract}
Two molecular cages have been tested as receptors for the persistent organic pollutant chlordecone. Whereas the host bearing amide functions displays a moderate binding constant $\left(126 \mathrm{M}^{-1}\right)$, the receptor with a tris(2-aminoethyl)amine moiety exhibits a higher association constant $\left(2.1 \times 10^{4} \mathrm{M}^{-1}\right)$. The recognition process was investigated by NMR experiments and DFT calculations.
\end{abstract}

Chlordecone (CLD) is an organochlorine insecticide that presents a rare perchlorinated bishomocubane structure (Fig. 1). Due to cyclic constraint and electron withdrawing effects, the ketone moiety of CLD can readily hydrate, both in the neat form and in organic solution (benzene, acetone, acetonitrile) when exposed to air moisture. ${ }^{1,2}$ All these specificities render the hydrophobic molecule slightly soluble in water (from roughly $2 \mathrm{mg} \mathrm{L}^{-1}$ at acidic and neutral $\mathrm{pH}$ to $176 \mathrm{mg} \mathrm{L}^{-1}$ at $\left.\mathrm{pH} 10.9\right)^{3}$ and very recalcitrant towards environmental conditions. ${ }^{4}$ In the laboratory, CLD was successfully degraded into hydrochlordecone and polychloroindene derivatives, using either chemical reductants, ${ }^{5}$ UV-irradiation ${ }^{1}$ or microorganisms. ${ }^{6}$ CLD was widely used from 1958 to the beginning of the 1990s, in particular in the French West Indies in order to fight against the banana black weevil cosmopolites sordidus, which attacks at the roots of banana trees. However, CLD has proven to be highly toxic to humans, hence its use was forbidden in Guadeloupe and Martinique in 1993. Indeed, epidemiological and toxicological studies have proven that CLD is both toxic for central nervous system and an endocrine-disrupting chemical; furthermore, it is considered as responsible for the increase in the risk of prostate cancer observed for people living in the

\footnotetext{
${ }^{a}$ Aix Marseille Univ, CNRS, Centrale Marseille, iSm2, Marseille, France. E-mail: alexandre.martinez@centrale-marseille.fr

${ }^{b}$ Laboratoire de Chimie, École Normale Supérieure de Lyon, CNRS, UCBL, 46 Allée d'Italie, F-69364 Lyon, France

${ }^{c}$ Laboratoire de Chimie Quantique Institut de Chimie, UMR CNRS 7177, Université de Strasbourg, 4, rue Blaise Pascal, F-67070 Strasbourg, France

${ }^{d}$ Génomique Métabolique, Genoscope, Institut François Jacob, CEA, CNRS, Univ Evry, Université Paris-Saclay, 91057 Evry, France.

E-mail: plsaaidi@genoscope.cns.fr
}

surrounding site where CLD was used. ${ }^{7}$ Moreover, CLD remains in the soils, crops and rivers, leading to a persistent environmental pollution and has been classified as Persistent Organic Pollutants (POPs) in 2009. ${ }^{4}$ CLD is extremely hard to remove from drinking water, hence it can still be found in the blood of people from the French West Indies. Thus, the supramolecular recognition of CLD is related to both environmental and health issues since it will allow its easier detection and its removal from water.

In this context, a host-guest approach appears as particularly appealing to bring new insight into the purification of water contaminated by CLD. ${ }^{8}$ Nevertheless, the complexation of CLD, a large poly-chlorinated compound, by host molecules has been rarely reported. To the best of our knowledge, only one example dealing with recognition of CLD by cyclodextrins has been described. ${ }^{9}$ However, no titration curve or association constant was given, preventing to estimate the strength of the binding. Moreover, after $4 \mathrm{~h}$, the uncomplexed cyclodextrin was restored, showing the weak stability of the host-guest complex with time. Among the hosts capable of complexation of guest molecules like cyclodextrins, ${ }^{10}$ calixarenes, ${ }^{11}$ or cucurbiturils, ${ }^{12}$ the hemicryptophanes built from a cyclotriveratrylene unit and another $C_{3}$ symmetrical moiety arouse a growing interest. ${ }^{13}$ Indeed, they have been proven to be efficient and selective receptors for cations, ${ }^{14}$ ionpairs, ${ }^{15}$ zwitterions, ${ }^{16}$ and carbohydrates. ${ }^{17}$ Nevertheless, they were mainly limited to ionic or sugar guests, which are hydrophilic substrates. However, the cavity of hemicryptophanes, capped on the upper part with a hydrophobic CTV unit and on the lower part with a polar moiety should be able to recognize CLD.

Here we report on the efficient recognition of CLD by the known hemicryptophanes 1 and 2 (Fig. 1). A very high binding constant of $2.1 \times 10^{4} \mathrm{M}^{-1}$ was obtained with host 2 . DFT calculations were performed and highlighted the perfect fit between the cavity size and that of the CLD. The nature of the interactions responsible for this very efficient recognition process is also discussed.

Hemicryptophane 1 was synthesized according to our published procedure in order to investigate its recognition properties toward CLD. ${ }^{18}$ The amide units in the south part were expected to give rise 

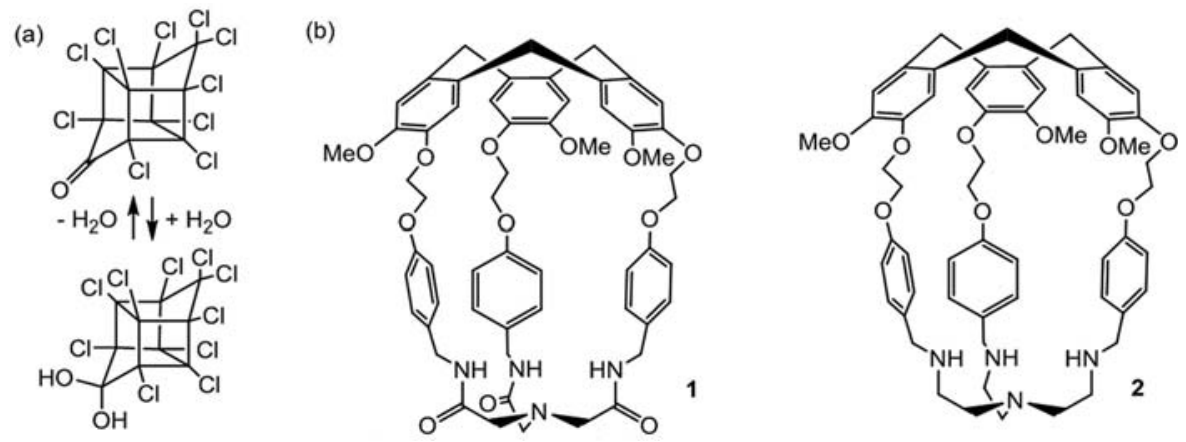

Fig. 1 (a) Structure of chlordecone and its hydrate form, (b) structure of hemicryptophanes 1 and 2.

to hydrogen bonds with the $\mathrm{OH}$ group of the CLD, as the gem diol structure of CLD is the major one in solution (Fig. 1). The binding constant was determined by ${ }^{1} \mathrm{H}$ NMR titration experiments in $\mathrm{CDCl}_{3}$ at $298 \mathrm{~K}$. NMR spectra were recorded after progressive addition of CLD to a solution of the receptor. In each case, only one set of signals was observed for the complex and for the free host, showing that host-guest exchange is fast on the NMR time scale, as usually observed in recognition processes involving hemicryptophanes. Complexation induced shifts of the aromatic $\mathrm{H}$ of the linkers at $6.4 \mathrm{ppm}$ on the receptor were plotted as a function of the guest/host ratio (Fig. 2). The resulting curves were fitted using Bindfit program and a 1:1 model to give a moderate binding constant of $126 \mathrm{M}^{-1} \cdot{ }^{19}$ Both the high rigidity and the small size of the cavity could account for this modest association constant. Thus, to improve the efficiency of the recognition process, host 2 was used as receptor for CLD: removal of the amide units should provide both more flexibility and space inside the cavity. ${ }^{20}$

${ }^{1} \mathrm{H}$ NMR titration experiments were therefore also performed with host 2 (Fig. 3). In that case, variations in the chemical shift upon addition of the guest are also observed, showing that the host-guest equilibrium is also fast on the NMR time scale. The complexation of the chlordecone molecule induces both upfield shift and a broadening of most of the NMR signals of cage 2 . In particular, the two well-defined doublets at $3.4 \mathrm{ppm}$, which correspond to the diastereotopic $\mathrm{Ar}-\mathrm{CH}_{2}-\mathrm{N}-$ protons, give a broad signal upon addition of CLD. (Fig. 3(a)). Moreover, a

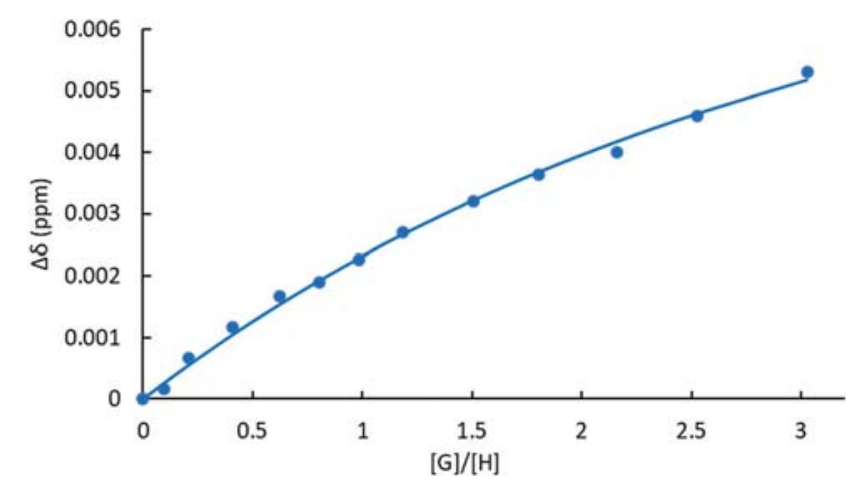

Fig. $2{ }^{1} \mathrm{H}$ NMR titration curves for the complexation of chlordecone (7 $\mathrm{mM})$ with host 1 (3 $\mathrm{mM})$. The chemical induced shifts $\Delta \delta$ of host's protons at $6.4 \mathrm{ppm}$ (the aromatic $\mathrm{H}$ of the linkers) were used. (a)

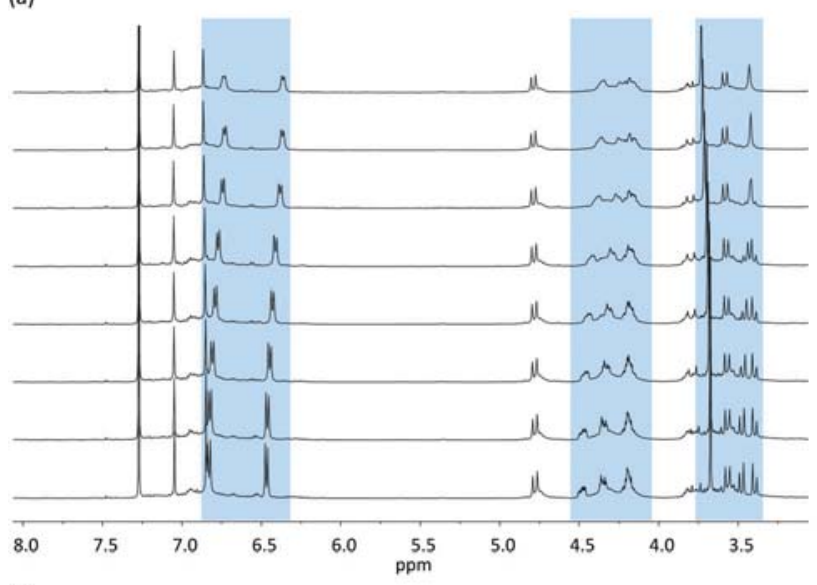

(b)

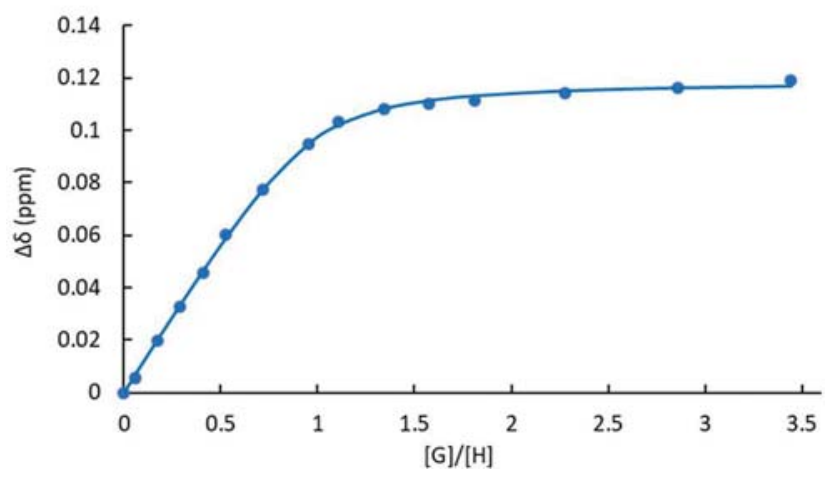

Fig. 3 (a) ${ }^{1} \mathrm{H}$ NMR spectra $\left(500 \mathrm{MHz}, \mathrm{CDCl}_{3}, 298 \mathrm{~K}\right.$ ) of host 2 upon progressive addition of chlordecone $(0,0.17,0.29,0.53,0.72,0.95,1.1$ and 2.3 equivalents from bottom to top). (b) ${ }^{1} \mathrm{H}$ NMR titration curves for the complexation of chlordecone $(7 \mathrm{mM})$ with host $2(3 \mathrm{mM})$. The chemical induced shifts $\Delta \delta$ of host's protons at $6.4 \mathrm{ppm}$ were used.

strong change in the slope of the titration curve was observed after addition of 1 equivalent of CLD, suggesting a high binding constant and confirming the expected 1:1 stoichiometry (Fig. 3(b)). The modelled curve gives an association constant of $2.1 \times 10^{4} \mathrm{M}^{-1}$, which validates our strategy and demonstrates the much higher affinity of host 2 toward CLD when compared to host 1. No change in the chemical shifts was observed after several days when a $1: 1$ ratio of CLD and hemicryptophane 2 were mixed in $\mathrm{CDCl}_{3}$ (Fig. S10 and S11, ESI $\dagger$ ). This is in sharp 
contrast with the previously described CLD@cyclodextrin complex, which turns out to be weakly stable with time. ${ }^{9}$

${ }^{13} \mathrm{C}$ NMR experiments were also performed to support the complexation of CLD by hemicryptophane 2 . Long-term ${ }^{13} \mathrm{C}$ NMR measurement of a CLD saturated solution in $\mathrm{CDCl}_{3}$ demonstrated the unique presence of the gem diol form as previously reported in acetonitrile and acetone. ${ }^{1}$ Indeed, the only five visible signals associated with CLD originated from the presence of two symmetrical planes in the CLD structure. Among them, the signal detected at $102 \mathrm{ppm}$ is characteristic of the gem diol function (Fig. S5, ESI $\dagger$ ). The signal integration ratio from a sub-saturated and a saturated solution of CLD enabled the solubility of CLD in $\mathrm{CDCl}_{3}$ to be estimated at $11.3 \pm$ $0.2 \mathrm{~g} \mathrm{~L}^{-1}$ (Fig. S6, ESI $\dagger$ ). For the complexation study, shorterterm acquisition parameters were used leading to only one detectable signal for CLD (Fig. 4(a)). The ${ }^{13} \mathrm{C}$ NMR spectrum of a mixture of CLD and cage 2 , recorded with exactly the same acquisition parameters, exhibits the expected signals of the cage, but with additional signals corresponding to CLD. Indeed, the complexation of CLD by host 2 increases its solubility, accounting for this experimental result. This increase in solubility of the guest was further confirmed by the following experiment: to a saturated solution of CLD, hemicryptophane 2 was added, and further addition of solid CLD to the mixture did not lead to any precipitate, demonstrating the improvement of the solubility of the guest. Thus, the ${ }^{13} \mathrm{C}$ NMR spectrum of the host/guest mixture shows well-defined and clear signals for the encaged CLD within the cavity of the receptor (Fig. 4). It can be noted that the same acquisition parameters were used for both set of experiments. Moreover, the direct comparison between the ${ }^{13} \mathrm{C}$ NMR spectra of
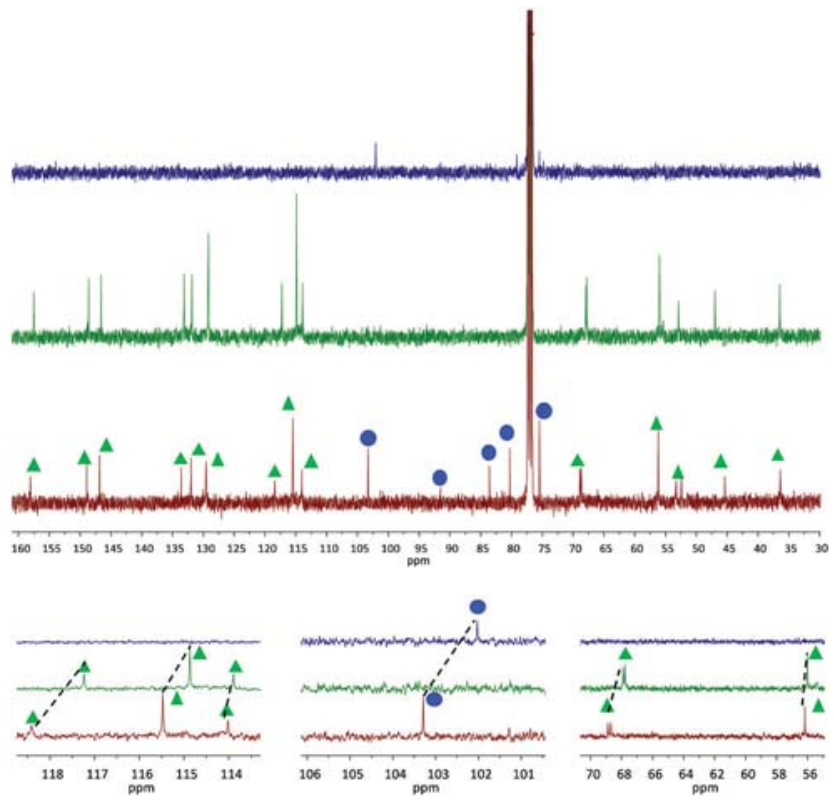

Fig. $4{ }^{13} \mathrm{C}$ NMR spectra in $\mathrm{CDCl}_{3}$ of (a) chlordecone (saturated solution) (blue), host $\mathbf{2}$ (green), mixture of host $\mathbf{2}$ and chlordecone (red) and (b) focus on some specific changes in the chemical shift of either the guest or the host upon complexation. The correspond to the signals of chlordecone and the $\boldsymbol{A}$ to the signals of hemicryptophane $\mathbf{2}$.

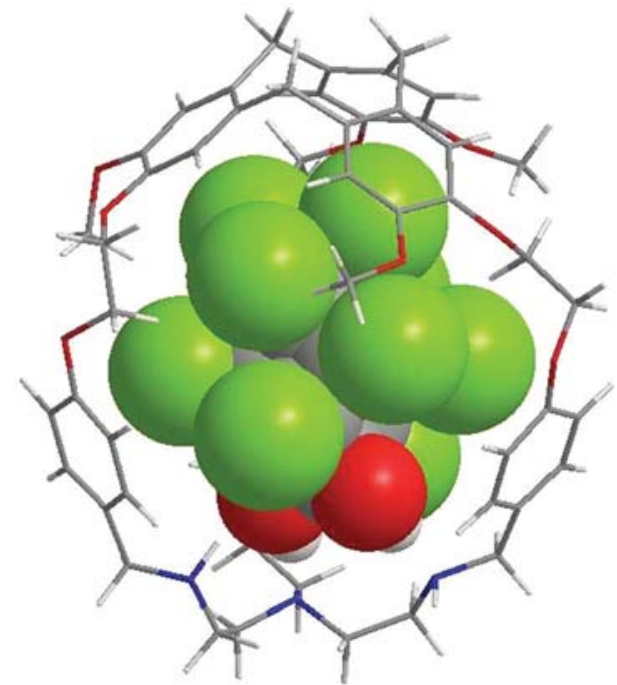

Fig. 5 DFT-optimized structures of chlordecone@2

the free CLD or the empty host 2, highlights changes in their chemical shifts, underlining the interaction between the two partners (Fig. 4(b)). This high binding constant and the lack of host-guest complex decomposition with time, prompted us to examine which interactions are involved in this very efficient complexation process, using Density Functional Theory (DFT) calculations.

The DFT optimized structure of the complex reveals that CLD is fully encaged in the hemicryptophane cavity (Fig. 5). Hydrogen bonding between the gem diol moiety and the nitrogen of the tren unit can be observed $\left(\mathrm{N}^{+} \mathrm{H} \cdots \mathrm{O}\right.$ distances between $2.580 \AA$ and $2.254 \AA$; and $\mathrm{N}$...HO distances between $2.156 \AA$ and $2.264 \AA$ ). . Moreover, the host/guest structure reveals halogen $-\pi$ interactions between the chlorine atoms of CLD and the aromatic rings of both the CTV units and the linkers (several $\mathrm{C}_{\mathrm{ar}} \cdots \mathrm{Cl}$ distances typically in the range of $3.1 \AA$ ). (a)

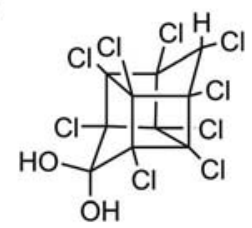

(c)

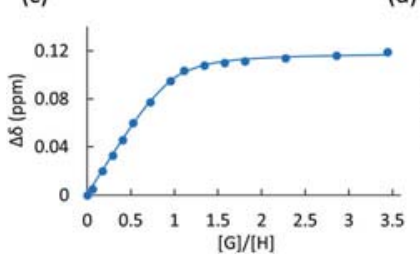

(b)

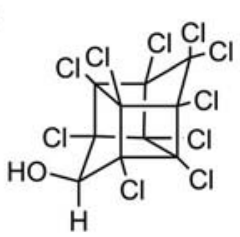

Fig. 6 Structures of (a) monohydrochlordecone and (b) chlordecone alcohol. ${ }^{1} \mathrm{H}$ NMR titration curves for the complexation of $(\mathrm{c}) 10-$ monohydrochlordecone $(7 \mathrm{mM})$ and $(\mathrm{d})$ chlordecone alcohol $(7 \mathrm{mM})$ with hemicryptophane 2 (3 mM). The chemical induced shifts $\Delta \delta$ of host's protons at $6.4 \mathrm{ppm}$ were used. 
All together, these interactions strongly stabilize the CLD@2 complex, accounting for the high binding constant measured. Interestingly, as the CLD molecule also presents a cage framework, this structure can be viewed as a cage into a cage.

Then, we studied the ability of cage 2 to complex two other derivatives of CLD: 10-monohydrochlordecone and chlordecone alcohol, which are also persistent pollutants detected in the French West Indies (Fig. 6). Binding constants were obtained using the same methodology as that described for CLD (Fig. 6). 10-Monohydrochlordecone is also well recognized by host 2 , with a binding constant of $2.6 \times 10^{4} \mathrm{M}^{-1}$, slightly higher than that of CLD. The replacement of one chlorine by a hydrogen atom probably releases the steric constrain in the host-guest complex and facilitates the recognition process. In contrast, chlordecone alcohol exhibits a much lower affinity with a binding constant of $136 \mathrm{M}^{-1}$, two orders of magnitude lower than CLD. This highlights the crucial role played by the hydrogen bonding between the two $\mathrm{OH}$ unit of CLD and the nitrogen atoms of host 2, as observed in the DFT minimized structure of the host-guest complex (Fig. 5).

In summary, we have described the efficient recognition of CLD, an Organic Persistent Pollutant, by a molecular host, which is, to the best of our knowledge, unprecedented. NMR titration experiments allowed estimating a high binding constant of $2.1 \times 10^{4} \mathrm{M}^{-1}$. DFT calculations underline interactions responsible of the encapsulation of CLD. Syntheses of watersoluble and fluorescent hosts are in progress in our laboratory in order to complex and detect easily CLD in water.

1 N. K. Wilson and R. D. Zehr, J. Org. Chem., 1979, 44, 1278-1282.

2 R. L. Harless, D. E. Harris, G. W. Sovocool, R. D. Zehr, N. K. Wilson and E. O. Oswald, Biomed. Mass Spectrom., 1978, 5, 232-237.

3 G. W. Dawson, W. C. Weimer and S. J. Shupe, The American Institute of Chemical Engineers (AIChE) Symposium Series, 1979, 75, 366.
4 M. Lesueur Jannoyer, P. Cattan, T. Woignier and F. Clostre, Crisis Management of Chronic Pollution: Contaminated Soil and Human Health, CRC Press, Boca Raton, 2016.

5 G. N. Schrauzer and R. N. Katz, Bioinorg. Chem., 1978, 9, 123-143.

6 S. Chaussonnerie, P.-L. Saaidi, E. Ugarte, A. Barbance, A. Fossey, V. Barbe, G. Gyapay, T. Bruls, M. Chevallier, L. Couturat, S. Fouteau, D. Muselet, E. Pateau, G. N. Cohen, N. Fonknechten, J. Weissenbach and D. Le Paslier, Front. Microbiol., 2016, 7, 2025.

7 (a) L. Multigner, J. R. Ndong, A. Giusti, M. Romana, H. Delacroix-Maillard, S. Cordier, B. Jégou, J.-P. Thome and P.-J. Blanchet, Clin. Oncol., 2010, 28, 3457-3462; (b) L. Multigner, P. Kadhel, F. Rouget, P. Blanchet and S. Cordier, Environ. Sci. Pollut. Res. Int., 2016, 23, 3-8; (c) S. Cordier, E. Bouquet, C. Warembourg, C. Massart, F. Rouget, P. Kadhel, H. Bataille, C. Monfort, O. Boucher, G. Muckle and L. Multigner, Environ. Res., 2015, 138, 271-278; (d) E. Emeville, A. Giusti, X. Coumoul, J. P. Thomé, P. Blanchet and L. Multigner, Environ. Health Perspect., 2015, 123, 317-323.

8 J. W. Steed and J. L. Atwood, Supramolecular Chemistry, Wiley, 2nd edn, 2009.

9 V. K. Rana, R. Kissner, S. Gaspard and J. LevaloisGrützmacher, Chem. Eng. J., 2016, 293, 82-89.

10 (a) G. Crini, Chem. Rev., 2014, 114, 10940-10975; (b) S. Roland, J. M. Suarez and M. Sollogoub, Chem. - Eur. J., 2018, 24, 12464-12473.

11 (a) D. S. Kim and J. L. Sessler, Chem. Soc. Rev., 2015, 44, 532-546; (b) L. Adriaenssens and P. Ballester, Chem. Soc. Rev., 2013, 42, 3261-3277; (c) F. Sansone and A. Casnati, Chem. Soc. Rev., 2013, 42, 4623-4639; (d) A. Jana, S. Bähring, M. Ishida, S. Goeb, D. Canevet, M. Sallé, J. O. Jeppesen and J. L. Sessler, Chem. Soc. Rev., 2018, 47, 5614-5645; (e) Anion Receptors Based on Calixarenes. P. Lhoták, Topics in Current Chemistry, ed. I. Stibor, 2005; $(f)$ M. De Rosa, P. La Manna, C. Talotta, A. Soriente, C. Gaeta and P. Neri, Front. Chem., 2018, 6, 84.

12 J. Murray, K. Kim, T. Ogoshi, W. Yao and B. C. Gibb, Chem. Soc. Rev., 2017, 46, 2479-2496.

13 (a) J. Canceill, A. Collet, J. Gabard, F. Kotzyba-Hibert and J.-M. Lehn, Helv. Chim. Acta, 1982, 65, 1894-1897; (b) D. Zhang, A. Martinez and J.-P. Dutasta, Chem. Rev., 2017, 117, 4900-4942.

14 (a) A. Schmitt, B. Chatelet, S. Collin, J.-P. Dutasta and A. Martinez, Chirality, 2013, 25, 475-479; (b) Y. Makita, N. Katayama, H.-H. Lee, T. Abe, K. Sogawa, A. Nomoto, S.-I. Fujiwara and A. Ogawa, Tetrahedron Lett., 2016, 57, 5112-5115.

15 O. Perraud, V. Robert, A. Martinez and J.-P. Dutasta, Chem. Eur. J., 2011, 17, 4177-4182.

16 (a) D. Zhang, G. Gao, L. Guy, V. Robert, J.-P. Dutasta and A. Martinez, Chem. Commun., 2015, 51, 2679-2682; (b) O. Perraud, V. Robert, H. Gornitzka, A. Martinez and J.-P. Dutasta, Angew. Chem., Int. Ed., 2012, 51, 504-508. 
17 (a) O. Perraud, A. Martinez and J.-P. Dutasta, Chem. Commun., 2011, 47, 5861-5863; (b) A. Long, O. Perraud, M. Albalat, V. Robert, J.-P. Dutasta and A. Martinez, J. Org. Chem., 2018, 83, 6301-6306.

18 P. D. Raytchev, O. Perraud, C. Aronica, A. Martinez and J.-P. Dutasta, J. Org. Chem., 2010, 75, 2099-2102.
19 D. B. Hibbert and P. Thordarson, Chem. Commun., 2016, 52, 12792-12805; URL: http://app.supramolecular.org/bind fit/.

20 B. Chatelet, E. Payet, O. Perraud, P. Dimitrov-Raytchev, L.-C. Chapellet, V. Dufaud, A. Martinez and J.-P. Dutasta, Org. Lett., 2011, 13, 3706. 